J. Perinat. Med. 5 (1977) 32

\section{Critical remarks on external cephalic version under tocolysis Report on a case of antepartum fetal death}

\author{
D. Berg, U. Kunze
}

Städt. Marienkrankenhaus Amberg
SALING and Müller-Holve [2] recently rediscovered the external version of breech into cephalic presentations and published the results of their first 57 cases in this Journal. Their procedure differs from the usual technique in some characteristics which have put a new emphasis on external versions when compared to the thoughts of other authors [1].

In spite of the undisputed advantages two questions occur, namely that of the resulting decrease of the cesarean section rate and that of the fetal risk. In order to stimulate a critical review of the method and to prevent a too enthusiastic rediscovery of the external version, we feel obligated to report on a fetal death associated with external version.

\section{Results of our own attempts at version}

If a breech presentation in primiparae is accepted as an indication for primary cesarean section and if the version is successful in $70 \%$, our section rate (1974: 9.3\%) would have decreased by $1 \%$. A further decrease, which is difficult to objectively assess, derives from multiparae where cesarean section is partly indicated by breech presentation but where a successful version would have made the operation unnecessary. We estimate the entire decrease of the cesarean section rate at $1.5 \%$.

Our ten versions are listed in Tab. I. Technique and timing of the versions followed the method described by SALING and MÜLLER-Holve [2]. The total dose of Partusisten ${ }^{\circledR}$ varied according to the duration of the pre-operative infusion and the time needed to establish the necessary depth of anesthesia. The infusion before the attempted version was at least 20 minutes in order to observe the fetal heart rate sufficiently well. The maternal diastolic blood pressure was in no case below $60 \mathrm{~mm} \mathrm{Hg}$. In seven cases the version was successful. The unsuccessful cases lead to a termination of the gestation by cesarean section; two of the successful versions were delivered by vacuum extraction. It is noteworthy that some cardiotocograms (CTG) after the procedures had markedly pathological patterns. Two of these cases will be discussed in more detail.

\section{Case reports}

Case 3

Successful version in the 37 th week of gestation in a 37 year-old para-3 woman. After the version the CTG showed tachycardia of the undulatory pattern with decreased variability. Delivery occurred in the 42 nd week from an occiput posterior position. The CTG at times was silent with occasional late decelerations. See Table for Apgar score and $\mathrm{pH}$ value. The infant now has spastic cerebral palsy.

\section{Case 10}

The 28 year-old primiparae was admitted in the 37 th week of gestation for external version of a breech presentation. There were no known complications of pregnancy. The biparietal diameter of the fetal head was $9.8 \mathrm{~cm}$, the placenta was posterior. The CTG was unremarkable on the day of admission with an undulatory pattern and at times decreased variability. This was interpreted (possibly erroneously) as representing fetal sleep.(Fig. 1, a). The 


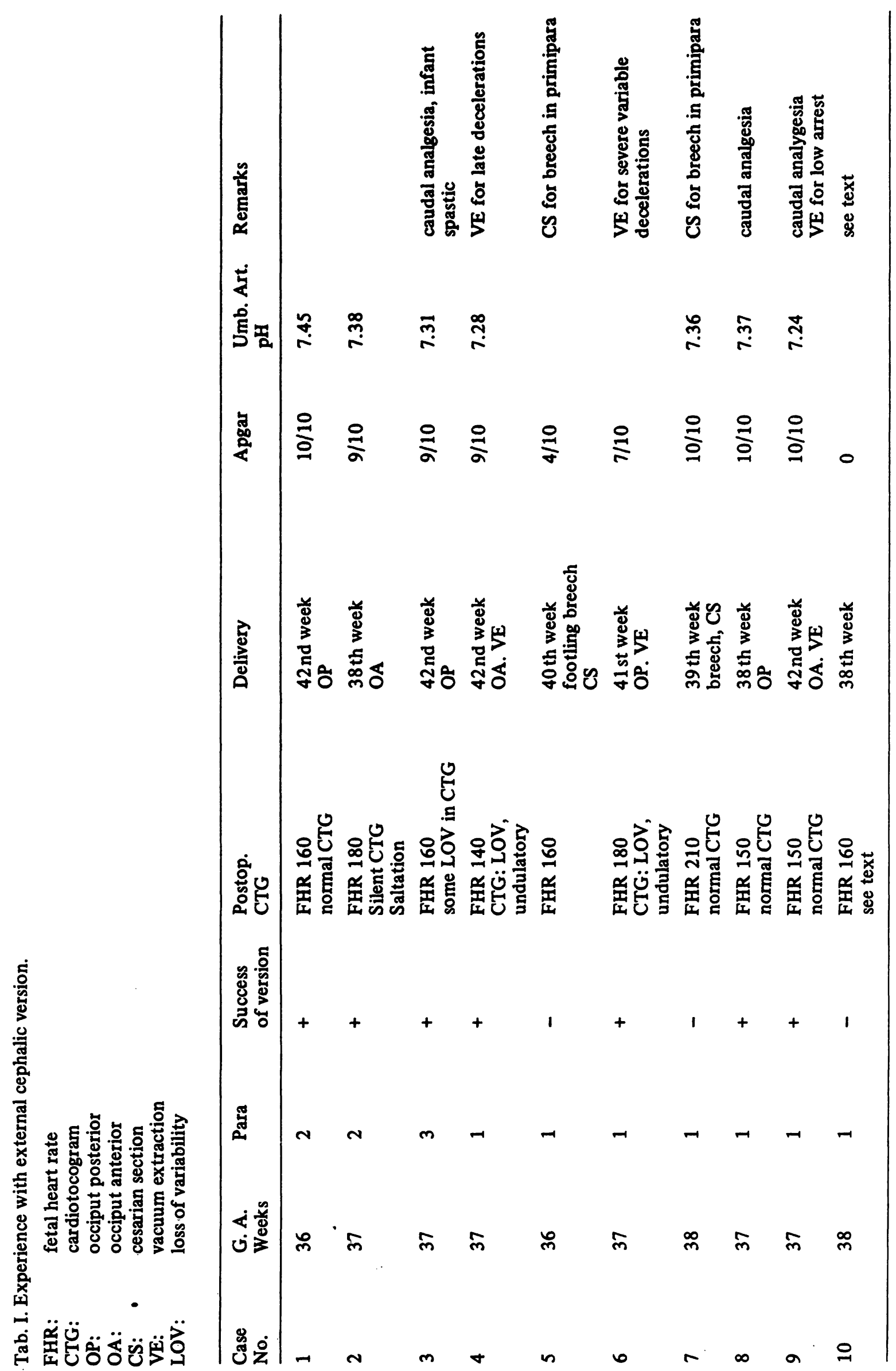


patient received Partusisten ${ }^{\circledR}$ orally. On the next day the pre-operative CTG showed undulation and decreased variability with mild tachycardia. This was thought to be due to the administration of Partusisten (Fig. 1, b). The version was attempted according to the method of SALING and failed since a too aggressive approach was avoided. Fetal bradycardia ensued, with a recovery after 5 minutes. Subsequently, the rate rose to 170 beats per minute. The CTG recording was technically poor, with a silent fluctuation pattern (Fig. 1, c). At times there was a sinus rhythm (Fig. 1,d). Towards the end of the recording technical deficiencies made the record appear to resemble almost a normal fluctuation (Fig. 1, e). The patient was monitored by cardiotocogram for four hours and remained clinically unremarkable. Seven hours after the attempted version the patient noted the absence of fetal movements and fetal heart tones could not be demonstrated. The patient was delivered of a recently expired mature fetus who weighed 3500 grams and was $53 \mathrm{~cm}$ long. The amniotic fluid was entirely clear; there was extensive epidermolysis. The placenta was submitted to Professor KLOOS in Berlin to whom we are indebted for the following findings:

Placenta weight 470 grams (80th percentile) in a large-for-dates infant (weigth and length above 90 th percentile). PQ 0.129 (normal 0.157). Torsion of the umbilical cord. Irregular oval-shaped placenta. Partial membraneous placenta at the margins measuring $13 \times 2$ to 3.5 to $1.5 \mathrm{~cm}$ in circumference. Marginal scar of $3 \times 1.5 \mathrm{~cm}$; deep diagonal groove basally of $14 \mathrm{~cm}$ in length. A pale placenta with occasional intermediate and central subacute focal villous collapse. In the vicinity of the marginal scar there were extensive confluent subacute chronic and acute infarcts. In this area there was a large retroplacental hematoma $(10 \mathrm{X}$ $8 \mathrm{~cm})$. Histologically this represents a severe dissociated anomaly of maturation. Several rami show embryonal arrest. Many plump rami have choroangiomatosis; in addition there are parts with interkalar arrest of ramification, i.e. premature maturation of terminal villi and lack of ramification. Severe signs of chronic disturbance of perfusion with subchorial pseudoinfarcts and many intervillous fibrinoid and focal collapse of villi. Many nuclear nodes. Occasional calcified encrustation of fibrin.

\section{Interpretation}

Placentogenic premature birth. Severe dyshormonosis, implantation damage and chronically disturbed perfusion of the placenta.

Suspected pre-diabetes (fetal hypertrophy and persistent embryonal villi structure). The fetal death during the stress of birth and procedure had its cause in the placenta.

No significant pathological findings were seen on autopsy of the infant.

In summary the following is remarkable:

1. This infant was pre-stressed 'from a placental cause and pre-diabetes. The extent of the placental disturbance was unknown and had not been suspected from the ultrasound findings.

2. The placentahad acute infarcts and acircumscript abruptio which had not lead to clinical symptoms.

3. The CTG findings were misinterpreted in part because of technical problems and the extent of the pathology was underestimated even though our department is fairly experienced with CTG.

\section{Discussion}

In comparison to the traditional method of the external version the technique of SALING and MÜLLER-HOLVE has two characteristics:

\section{Timing of the version}

The external version is carried out later in pregnancy i.e. at a time at which the fetal movements are less because of the decreased amount of amniotic fluid. Thus, the risk of the child reverting spontaneously into a breech presentation is less. Also, in an emergency which may be recognized by cardiotocography the infant can be delivered.

\section{Tocolysis}

Modern tocolytics such as Fenoterol (Partusisten ${ }^{\circledR}$ ) allow a deeper relaxation of the uterus and thus the external version at a later point in pregnancy. SALING and MUlLER-Holve were even successful in 3 of 6 cases during already established labor at term. This method is thus distinctly different from the external cephalic version in earlier pregnancy, the value of which has been questioned considerably by BRADLEY-WATSON.

The advantage of the method is evident and was impressively documented by SALING and MULLLERHOLVE with the improved scores of the clinical status and the acidity status. It might be argued that the improved status of the newborn not necessarily proves the harmlessness of the external version, but rather may represent a successful selection of the cases for versions. The clinical importance of the external version cannot be argued but it should not be over-estimated. A decrease of the cesarean section rate by $1.5 \%$, while 


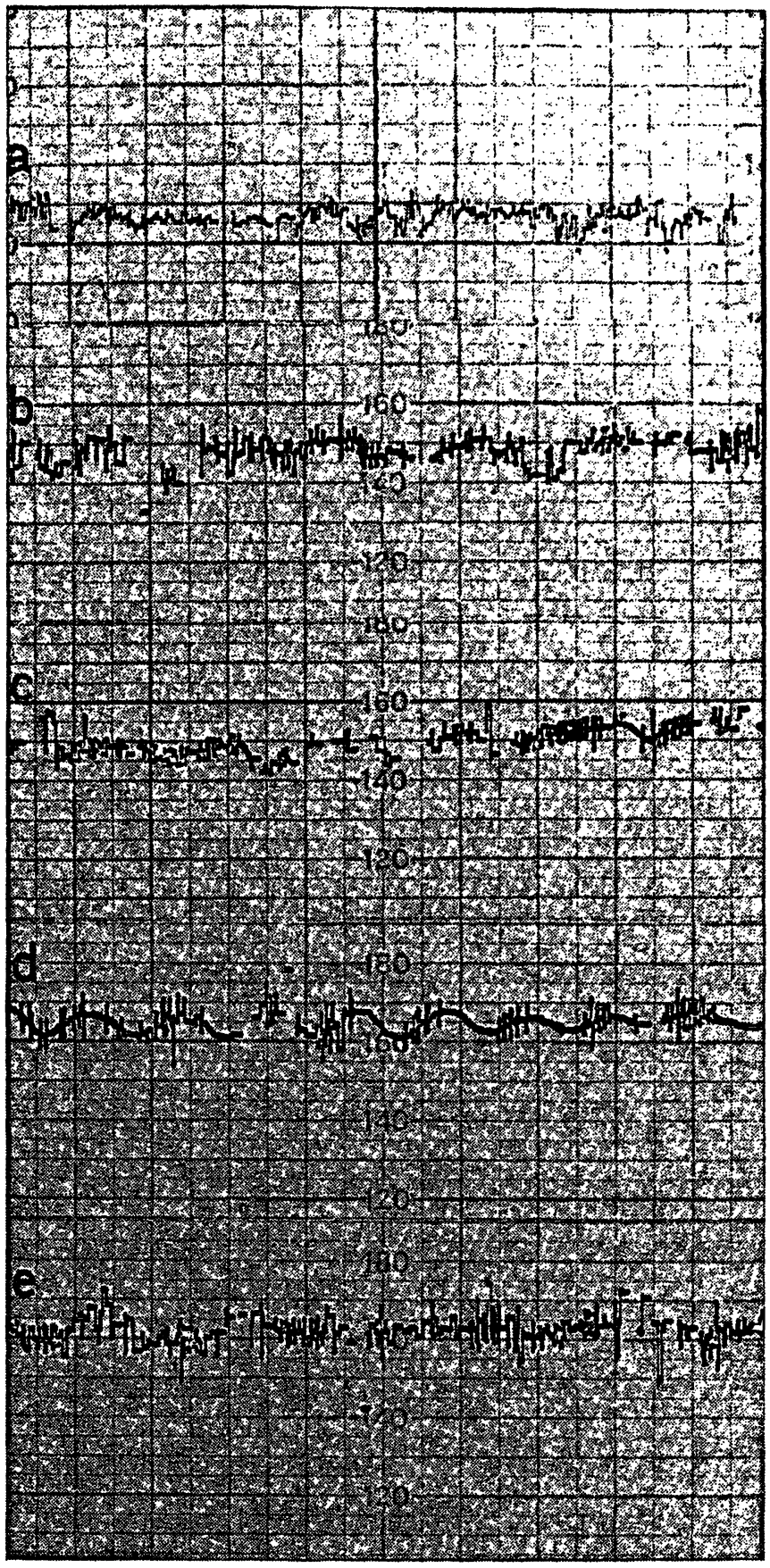

Fig. 1. CTG in a case of attempted external version with subsequent intrauterine fetal death.

Figure a CTG on the day before the attempted version

Figure b CTG immediately before the version with Partusisten ${ }^{\circledR}$ infusion

Figure c CTG after the attempted version

Figure d Sinusoid CTG after the attempted version

Figure e Technically poor CTG 4 hours after the attempted version which was thought to be normal

important in the individual cases, however, is not of great impact considering the current tendency toward higher cesarean section rates. It must be asked if effort and risk of versions are justified by this decrease of the section rate.
More difficult is the assessment of the fetal risk problem. SALING and MULleR-Holve described complications in two small-for-dates infants weighing less than 2300 grams. Our own results are even poorer. Only in 3 cases was the CTG after 
the version normal. These pathological fetal heart patternscannot be explained conclusively. However, our discussion and illustration of CTG changes compare the post-operative CTG with that one immediately before the procedure. This allows for practical purposes the exclusion of any role of the Partusisten ${ }^{\circledR}$ on the fetal heart rate. Complications from the umbilical cord or an increased pressure on the head can be excluded with great probability because this should result in deceleration. In our extensive experiments with the manipulation of the umbilical cord in fetal sheep we have never seen decelerations not to occur. However, it is possible that brief hypoxic insults of this pathogenesis excape observation because a continuous recording of the fetal heart rate during the version has not been carried out. On the other hand one would expect a more rapid recovery of the fluctuation pattern in umbilical cord complications.

Disturbances of the perfusion of the fetal side of the placenta also are not likely, because an increased amniotic pressure should act equally on fetus, umbilical cord and placenta.

Therefore, we suspect that the increased intraamniotic pressure - which we have measured to be in excess of $100 \mathrm{~mm} \mathrm{Hg}$ during external versionsacts - on the intervillous space which is squeezed empty toward the maternal circulation. The intervillous space represents the only "gap in the closed system of the gravid uterus." At the insertion of the spiral arteries into the intervillous space the spiral artery pressure is added to the intraamniotic pressure of about $100 \mathrm{~mm} \mathrm{Hg}$ during version. It is entirely imaginable that this would lead to ruptured vessels and the formation of the retroplacental hematoma and the premature abruption of the placenta as we unfortunately saw in the case reported.

Whether this hypothesis is correct or not: a decreased heart rate variability, tachycardia, and

\section{Summary}

SALING and MÜLLER-HOLVE recently proposed an improved method of external cephalic version brought about a renewed interest in this obstetric procedure. In spite of the undisputed advantages in individual cases we posed the following questions:

1. The extent of the decreased cesaerean section rate

2. The fetal risk bradycardia signify a risk whose etiology and extent must be clarified. Which sequelae result for the infant can only be istated when there are post-partum observations of a greater number. It is uncertain whether the central nervous system damage of Case 3 can be blamed on the version. An intracranial hemorrhage because of the high pressure during the version might be invoked. At the time of birth the child was well and the $\mathrm{pH}$ of the umbilical artery was normal.

The experiences of SALING and MưlLLER-Holve with their two small-for-dates infants and our own poor results show that it is important to select the patients for external version. In our opinion the existing criteria for selection and the precautions do not ensure the exclusion of all pre-stressed infants from the external version. Since the method of the external version is valuable and promising for individual cases, we wish to suggest the following precautionary measures so that the method is not entirely discredited:

1. No version in patients in which despite of existing breech presentation a normal vaginal delivery may be expected.

2. No version attempts in cases of anteriorly located placentas.

3. The results of the CTG, ultrasound, HPL, estriol must be normal and the patient's course should be well known.

4. Normal pre-operative CTG for one hour during the Partusisten ${ }^{\circledR}$ infusion.

5. The version must be done during good maternal hemodynamics with sufficient tocolysis and sufficient anesthesia.

6. Limit of force: ideal would be recording of the force used with yet to be designed transducers.

7. Not more than two version attempts of a total duration of 3 minutes.

8. CTG monitoring for another 8 hourș.

We estimate a decrease of cesarean sections by about $1.5 \%$ under the assumption that a breech presentation in primiparae is an indication of cesarean section and that $70 \%$ of the version attempts would be successful. The estimate includes some cases of multi-parae breech presentations which would have been operated without external version. 
The resulting decrease of the cesarean section rate is: generally not very important and has a greater impact only in individual cases.

We have some misgivings about the fetal risk. We report here on a case of intrauterine fetal death after failed external version. A 28 year-old primiparae without known pregnancy complications was admitted with a breech presentation in the 37 th week of gestation. The biparietal diameter of the fetal head was appropriate and the placenta was posterior. Cardiotocogram before and after the unsuccessful version were in part misinterpreted. Seven hours after the version the fetal death was confirmed. Histological examination of the placenta showed a severe dissociated maturation disturbance in addition to a $10 \times 8 \mathrm{~cm}$ large abruptio which had not been noted clinically. A prediabetes was suspected. The fetus itself showed no anomalies.

This was interpreted as a severely placentogenically prestressed infant and prediabetes. The extent of the placental disturbance was unknown and had not been appreciated from the ultrasound examination. The placenta had acute infarcts and a circumscript abruption. The CTG was misinterpreted in part. In another case of version the post- operative cardiotocogram showed pathologic patterns. The birth occurred three weeks later without problems with a well child and an umbilical artery $\mathrm{pH}$ of 7.31. However, this infant is now spastic. It is obviously questionable whether there is any causal connection with the version but on the other hand it cannot be excluded. In the discussion, the hypothesis is made that the intrauterine pressure of $100 \mathrm{~mm} \mathrm{Hg}$ (own measurements) might suffice to squeeze out the intervillous space of the placenta towards the maternal circulation. Thus, it would be possible to obtain pressures in the afferent and efferent maternal vessels sufficient to cause retroplacental hematomas and premature abruptio. This hypothesis is collaborated by our observation that in 6 of our 10 cases we have seen pathological CTG patterns following the version which cannot be explained by umbilical cord complications or head pressure phenomena.

Even if this hypothesis is incorrect, it is necessary to select cases for external cephalic version better. We suggest a series of precautionary measures the most important of which is a better assessment of fetal risk factors and a limit of the forces used as well as a longer monitoring phase.

Keywords: Abruptio, external cephalic version, intrauterine fetal death, tocolysis.

\section{Zusammenfassung}

Kritische Bemerkungen zur äußeren Wendung unter Tokolyse

Kasuistik eines antepartualen fetalen Todesfalles

SALING und MÜLLER-HOLVE haben kürzlich einen Verbesserungsvorschlag zur äußeren Wendung unterbreitet, der dieser geburtshilflichen Operation wieder zu größerer Beachtung verhalf. Trotz der im Einzelfall unstreitigen Vorteile stellte sich uns die Frage nach der resultierenden Verminderung der Sektiofrequenz und nach dem fetalen Risiko.

In unserem Geburtengut hätte sich die Sektio-Frequenż um insgesamt $1,5 \%$ unter der Voraussetzung vermindert, daß bei jeder I-Para-Beckenendlage eine Sektio indiziert gewesen und durch eine äußere Wendung in $70 \%$ der Fälle vermieden worden wäre. Eingeschlossen in diese $\mathrm{Zahl}$ sind einige Fälle von Mehrpara-Beckenendlagen, die man ohne äußere Wendung operiert hätte.

Die resultierende Verminderung der Sektio-Frequenz ist generell nicht sehr bedeutend und nur im Einzelfall von größerem Nutzen.

Ernster wird von uns die Frage nach dem fetalen Risiko beantwortet. In der vorliegenden Arbeit wird über einen Fall von intrauterinem Fruchttod nach vergeblichem Wendungsmanöver berichtet. Eine 28-jährige I-Para wurde in der 37. Schwangerschaftswoche wegen Beckenendlage zur äußeren Wendung eingewiesen. Schwangerschaftskomplikationen waren nicht bekannt, der biparietale Durchmesser des kindlichen Kopfes war entsprechend groß, die Plazenta an der Hinterwand gelegen. Kardiotokographische Kontrollen vor und nach dem Wendungsversuch, der erfolglos abgebrochen werden mußte, wurden durchgeführt, die Befunde jedoch teilweise falsch interpretiert. Etwa 7 Stunden nach dem Wendungsversuch mußte der intrauterine Fruchttod festgestellt werden. Die histolo- gische Untersuchung der Plazenta ergab neben dem Befund einer $10 \times 8 \mathrm{~cm}$ großen, klinisch unbemerkt gebliebenen vorzeitigen Lösung eine schwere dissoziierte Reifungsstörung. Es wurde der Verdacht auf Prädiabetes geäußert. Das Kind selbst wies keine auffälligen Veränderungen auf. Zusammenfassend handelte es sich bei diesem Fall um ein schwer plazentogen vorgeschädigtes Kind bei Prädiabetes. Das Ausmaß der Plazentastörung war unbekannt und bei der alleinigen Ultraschalluntersuchung nicht festzustellen. In der Plazenta fanden sich akute Infarkte und eine umschriebene vorzeitige Lösung. Das CTG wurde stellenweise fehlinterpretiert.

In einem weiteren Fall von vorzeitiger Wendung zeigten sich im postoperativen Kardiotokogramm pathologische Verläufe. Die 3 Wochen später erfolgende Geburt des Kindes verlief ohne größere Besonderheiten, das Kind war lebensfrisch und wies ein Nabelarterien-pH von 7,31 auf. Dieses Kind ist heute spastisch. Ob ein Kausalzusammenhang mit der Wendung besteht, ist natürlich fraglich, allerdings auch nicht sicher auszuschließen.

In der Diskussion wird die Hypothese aufgestellt, daß die bei der Wendung erreichten intrauterinen Drucke von etwa $100 \mathrm{mmHg}$ (eigene intrauterine Messungen) ausreichen könnten, den intervillösen Raum der Plazenta in Richtung auf die mütterliche Zirkulation auszupressen. Dadurch entstehen möglicherweise im Bereich der zu- und abführenden mütterlichen Gefäße Drucke, die zur Bildung von retroplazentaren Hämatomen im Sinne von vorzeitigen Lösungen führen. Für diese Hypothese spricht unsere Vermutung, daß wir in 6 von 10 Fällen pathologische CTG-Muster nach der Wendung beobachtet haben, die durch Nabelschnurkomplikationen oder Kopfdruckphänomene nicht zu erklären sind.

Auch wenn diese Hypothese nicht zutrifft, ist eine bessere 
Selektion der Fälle erforderlich, die der äußeren Wendung zugefuihrt werden können. Wir schlagen eine Reihe von Vorsichtsmaßnahmen vor, deren wichtigste eine breitere
Erfassung fetaler Risikofaktoren, eine Limitierung der Kraftanwendung und eine verlängerte Überwachungsphase sind.

Schlüsselwörter: Äußere Wendung, intrauteriner Fruchttod, Tokolyse, vorzeitige Lösung.

\section{Résumé}

Remarques critiques sur la rotation externe sous tocolyse Casuistique d'une mort foetale intrautérine

SALING et MÜLLER-HOLVE ont élaboré récemment un moyen d'améliorer la rotation externe, ce qui a eu l'avantage d'attirer à nouveau l'attention sur cette intervention obstétrique. Malgré les avantages incontestables de ce procédé dans divers cas particuliers, il ne nous a pas paru avoir résolu les problèmes de

1. la réduction consécutive de la fréquence des sections et 2. du risque foetal.

Nous avons donc tenté d'étudier ces deux questions.

$\mathrm{Si}$ on considère l'ensemble de nos accouchements, on constate que la fréquence des sections aurait diminué de $1,5 \%$ au total, compte tenu de ce que pour chaque cas de position du siège primipare une section aurait été indiquée, puis évitée dans $70 \%$ des cas grâce à une rotation externe du foetus. Ce nombre inclut plusieurs cas de positions du siège multipares qu'on aurait opéré si on n'avait pas effectué de rotation externe. La réduction consécutive de la fréquence des sections n'est pas très significative en général et ne peut révéler un indice utile que dans des cas particuliers.

Par contre, la question relative qu risque foetal a abouti à un résultat plus sérieux. L'article présent traite d'un cas de mort foetale intrautérine après une vaine tentative de rotation. Une femme primipare de 28 ans en 37ème semaine de grossesse a été envoyée à l'hôpital pour rotation externe après observation d'une position du siège. Aucune complication de grossesse n'avait été enregistrée, le diamètre bipariétal de la tête du foetus était proportionnellement grand et le placenta appliqué à la paroi postérieure. Des contrôles cardiotocographiques avant et après la tentative de rotation, qui avait dû être interrompue sans succès, ont été effectués avec, toutefois, une interprétation partiellement fausse des résultats. 7 heures environ après l'essai de rotation on a dû constater la mort foetale intrautérine. L'examen histologique du placenta a révélé, outre un détachement de $10 \times 8 \mathrm{~cm}$ précoce et non apparent à l'observation clinique, un trouble de maturation dissocié grave. La question d'un prédiabète s'est posée. L'enfant lui-mêmen'a montré aucune altération marquante. En résumé, il s'agissait dans ce cas de prédiabète grave du foetus. On n'avait pu mesurer l'étendue de l'altération placentaire et le seul examen ultrasonore n'y a pas suffi. On releva dans le placenta des infarctus aigus et un détachement circonscrit prématuré. Le CTG a été partiellement mal interprété.

Dans un autre cas de rotation précoce, le cardiotocogramme post-opératoire a révélé des développements pathologiques. La naissance qui a suivi 3 semaines plus tard s'est déroulée sans rien de bien particulier, l'enfant était bien vivant avec un pH de l'artère ombilicale de 7,31. Or, cet enfant est aujourd'hui spastique. Existe-t-il un rapport de causalité avec la rotation? Cette possibilité n'est pas évidente, mais n'est certainement pas à exclure. La discussion soulève l'hypothèse que les pressions intrautérines d'environ $100 \mathrm{mmHg}$ (mesures intrautérines propres) atteintes par rotation pourraient suffire à expulser l'espace intervilleux du placenta vers la circulation maternelle, et il est possible que cela occasionne dans la région des vaisseaux maternels afférents et déférents des pressions qui provoquent la formation d'hématomes rétroplacentaires sous forme de déta-chements précoces. Cette hypothèse semble justifièe par l'observation que nous avons faite dans 10 cas dont 6 avaient montré après rotation des échantillons pathologiques qui ne sauraient s'expliquer par des complications du cordon ombilical ou des phénomènes de pression de la tête.

Et même si cette hypothèse ne s'avère pas juste, il est indispensable d'opérer une meilleure sélection des cas devant subir une rotation. A cet effet nous proposons une série de mesures de précaution dont la plus importante comprènd l'établissement d'une liste plus grande des facteurs de risque pour le foetus, une limitation de l'application des forces et une période de surveillance plus étendue.

Mots-clés: Détachement précoce, mort foetale intrautérine, rotation externe, tocolyse.

\section{Bibliography}

[1] BRADLEY-WATSON, P. J.: The decreasing value of external cephalic version in modern obstetric practice. Amer. J. Obstet. Gynec. 123 (1975) 237
[2] SALING, E., MÜLLER-HOLVE, W.: External cephalic version under tocolysis. J. Perinat. Med. 3 (1975) 115

Received March 3, 1976. Accepted May 7, 1976.
Prof. Dr. Dietrich Berg

Ulirich Kunze

D-845 Amberg

Städt. Krankenhaus 